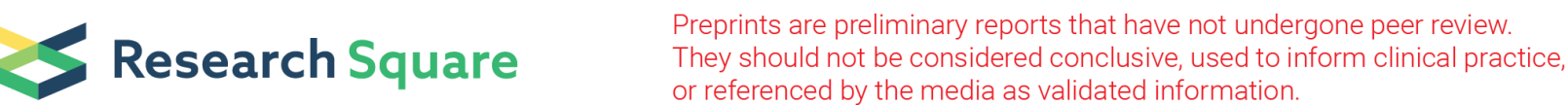

\section{Low prevalence of hypertension in children with renal cysts and diabetes syndrome is the hallmark of the disease}

\section{Tomas Seeman ( $\nabla$ tomas.seeman@lfmotol.cuni.cz)}

Universitat München: Ludwig-Maximilians-Universitat Munchen https://orcid.org/0000-0003-13713096

\section{Friederike Weigel}

Friedrich Schiller University Jena: Friedrich-Schiller-Universitat Jena

\section{Kveta Blahova}

Prague Charles University, 2nd Medical Faculty

\section{Filip Fencle}

Charles University: Univerzita Karlova

\section{Stepanka Pruhova}

Charles University: Univerzita Karlova

\section{Katharina Hermes}

Ludwig-Maximilians-Universitat Munchen

\section{Richard Klaus}

Ludwig-Maximilians-Universität München: Ludwig-Maximilians-Universitat Munchen

\section{Bärbel Lange-Sperandio}

Ludwig-Maximilians-Universität München: Ludwig-Maximilians-Universitat Munchen

\section{Veit Grote}

Ludwig-Maximilians-Universität München: Ludwig-Maximilians-Universitat Munchen

\section{Ulrike John-Kroegel}

Friedrich-Schiller-Universität Jena: Friedrich-Schiller-Universitat Jena

\section{Research Article}

Keywords: HNF1B, Ambulatory blood pressure monitoring, Hypertension, Proteinuria, Albuminuria, Renal function

Posted Date: March 30th, 2021

DOI: https://doi.org/10.21203/rs.3.rs-325073/v1 
License: (c) (i) This work is licensed under a Creative Commons Attribution 4.0 International License. Read Full License 


\section{Abstract}

Cystic kidney diseases such as autosomal recessive or dominant polycystic kidney disease (ARPKD and ADPKD) are associated with high prevalence of arterial hypertension. On the contrary, studies on hypertension in children with renal cysts and diabetes (RCAD) syndrome caused by abnormalities in the $H N F 1 B$ gene are rare. Therefore, the aim of our study was to investigate the prevalence of hypertension in children with RCAD syndrome due to HNF1B gene abnormalities and to search for possible risk factors for development of hypertension.

Data on all children with genetically proven RCAD syndrome from three pediatric nephrology tertiary centers were retrospectively reviewed (office blood pressure (BP), ambulatory blood pressure monitoring (ABPM), creatinine clearance, renal ultrasound, echocardiography, albuminuria/proteinuria). Hypertension was defined using the current ESH 2016 criteria and/or by the use of antihypertensive drugs.

Thirty-two children with RCAD syndrome were investigated. Three children received ACE-inhibitors for hypertension and/or proteinuria. Hypertension was diagnosed using office BP in $22 \%$ of the children ( $n=$ 7) In the 7 performed ABPM 1 child (14\%) was diagnosed with hypertension. Creatinine clearance, proteinuria, albuminuria, body mass index, enlargement or hypodysplasia of the kidneys and prevalence of HNF1B-gene deletion or mutation were not significantly different between hypertensive and normotensive children.

Conclusion: Hypertension is rare in children with RCAD syndrome. The low prevalence of hypertension seems to be the hallmark of the disease.

\section{Introduction}

\section{What is known:}

Arterial hypertension is a common complication in children with polycystic kidney diseases.

\section{What is new}

Hypertension is a rare clinical manifestation of children with renal cyst and diabetes (RCAD) syndrome. The low prevalence of hypertension seems to be the hallmark of children with RCAD syndrome.

Cystic kidney diseases belong to the most common structural kidney abnormalities with autosomal dominant polycystic kidney disease (ADPKD) being the most common one and autosomal recessive polycystic kidney disease (ARPKD) being the most severe with high morbidity and mortality $[1,2]$. Both polycystic kidney diseases are associated with high prevalence of arterial hypertension in childhood. Elevated blood pressure is documented in $35 \%$ of children with ADPKD [3,4] and in $75 \%$ of children with ARPKD [2]. By contrast, studies on hypertension in children with renal cysts and diabetes (RCAD) 
syndrome due to HNF1B gene abnormalities are lacking. Adult patients with RCAD syndrome show a variable prevalence of hypertension ranging from $7 \%$ to $80 \%$ [5 - 7]. Only one pediatric study investigating patients with HNF1B mutations showed normal mean blood pressure (BP) in comparison to healthy children. Other pediatric studies on patients with RCAD syndrome did not give any data on BP or arterial hypertension.

Therefore, the aim of our study was to investigate the prevalence of hypertension in children with RCAD syndrome due to $H N F 1 B$ gene abnormalities and to search for possible risk factors for its development.

\section{Methods}

\section{Subjects}

A total of 32 children ( 20 boys and 12 girls) with RCAD syndrome were retrospectively analyzed using the medical records of three tertiary pediatric nephrology centres in Prague, Jena, and Munich. The inclusion criteria were genetically proven RCAD syndrome (whole HNF1B-gene deletion or pathogenic variant of the $H N F 1 B$-gene in combination with presence of any renal anomaly) and office BP data. Children with CKD stage 5 were excluded from the study. The median age was 3.0 years (range 0.3-18.5 years). The HNF1Bgene deletion was found in $72 \%$ of patients and a pathogenic variant of the HNF1B-gene in $28 \%$ of patients. Renal ultrasound was pathological prenatally in $48 \%$ of patients and postnatally in $52 \%$ of children. The median age at diagnosis was 3.0 years (range 1 day -18 years).

\section{Antihypertensive medication}

Three (9\%) children received ACE-inhibitors for hypertension and/or proteinuria. No child received any other antihypertensive medication at the time of the study.

\section{Office blood pressure measurement}

Office BP was measured using an oscillometric device Omron and hypertension ( $\mathrm{HT}$ ) was defined as systolic and/or diastolic BP $\geq 95$ th percentile according to the current ESH guidelines [8] and/or the use of antihypertensive medication.

\section{Ambulatory blood pressure monitoring (ABPM)}

ABPM was performed in 7 patients because of elevated OBP $(n=2)$ or because of CKD despite of normal OBP $(n=5)$. In the remaining 25 patients ABPM was not performed mainly because of normal office BP. ABPM studies were carried out using oscillometric SpaceLabs 90207 or 90217 monitors (SpaceLabs Medical, Redmont, WA). An appropriate cuff was placed on the non-dominant arm by a physician who also informed the child and parents in detail how to operate the monitoring system. Monitors were programmed to measure BP automatically every 20 min during the day and every $30 \mathrm{~min}$ at night. The criteria for omitting BP outliers from ABP recordings were systolic BP $>200$ and $<70 \mathrm{mmHg}$, diastolic BP $>150$ and $<40 \mathrm{mmHg}$, and mean arterial pressure (MAP) $>200$ and $<40 \mathrm{mmHg}$. According to the reference 
values by Wuhl et al. [9], data were analyzed by using an individualized daytime and nighttime period according to the individual diaries. Mean systolic and diastolic BP at daytime and nighttime were calculated. The BP index was calculated as mean BP, divided by the 95th percentile that was determined according to the body height and sex of the patient [9]. For children with body height $<120 \mathrm{~cm}$ the $95^{\text {th }}$ percentile was used for children with body height $120 \mathrm{~cm}$. Ambulatory HT was defined as systolic and/or diastolic mean BP at daytime and/or nighttime $\geq 95^{\text {th }}$ percentile.

\section{Urinary excretion of albumin and protein}

Freshly voided urine (first morning urine) was obtained for quantitative measurement of total protein (Biuret method), albumin (turbidimetry) and creatinine (enzymatic). Pathological albuminuria was defined as albumin/creatinine ratio $>3 \mathrm{mg} / \mathrm{mmol}$ creatinine and proteinuria as protein/creatinine ratio $>22$ $\mathrm{mg} / \mathrm{mmol}$ creatinine [10].

\section{Renal function}

Chronic kidney disease (CKD) stages 1 - 4 according to the K-DOQI guidelines were detected [K-DOQI] using estimated glomerular filtration rate according to the Schwartz formula using serum creatinine (enzymatic method) and body height [11]. Children with CKD stage 5 were excluded from the study.

\section{Renal ultrasonography}

Data on renal ultrasound findings were collected (cysts, renal length, dysplasia, dilation of renal pelvis). Kidney lengths were analysed, compared with normal standards and expressed as SDS [12].

\section{Echocardiography}

Echocardiogram (standard two-dimensional echocardiogram (GE/Wingmed system 5, Vivid 7, Horten, Norway) was performed in 8 children on the same day as the office BP measurement (according to the recommendations of the American Society of Echocardiography) [13]. Left ventricular mass (LVM), was calculated according to the formula of Devereux from the left ventricular internal dimension at end diastole, interventricular septal thickness and left ventricular posterior wall thickness [14]. Left ventricular mass was indexed to height2.7 (left ventricular mass index LVMI) to account for body size [15]. Left ventricular hypertrophy $(\mathrm{LVH})$ was defined as $L V M I \geq 95^{\text {th }}$ percentile for normative pediatric LVMI data [16].

\section{Extra-renal findings}

The extra-renal findings (maturity onset diabetes of the young - MODY, hypomagnesemia or liver abnormalities) and medical history data such as birth weight or oligohydramnios were collected retrospectively from the medical charts.

\section{Statistical analysis}


The data were analysed by using the STATA software package. SDS values of hypertensive and normotensive patients were investigated by using the Mann-Whitney $U$ test. Values with $p<0.05$ were considered statistically significant.

\section{Results}

\section{Office blood pressure measurement}

Seven out of 32 patients ( $22 \%$ ) were regarded as hypertensive on the basis of the office BP measurements or by the use of antihypertensive drugs. All hypertensive children had stage 1 hypertension. Three patients had isolated diastolic hypertension, three patients combined systolic and diastolic hypertension and no child had isolated systolic hypertension. One patient on ACEl therapy had normal office BP values. Among children with CKD stage $2-4(n=11) 36 \%$ were hypertensive on contrary to $14 \%$ in children with CKD stage 1 and normal eGFR $(p=0.13)$.

\section{Ambulatory blood pressure monitoring}

Only one patient from seven measured children (14\%) was found to have hypertension defined by ABPM. He had borderline isolated night-time diastolic hypertension with a diastolic BP of $65 \mathrm{mmHg}\left(95^{\text {th }}\right.$ percentile $65 \mathrm{mmHg}$ ). He had also hypertension defined by office BP. One patient had white-coat hypertension, no patient showed masked hypertension and five children were normotensive both by ABPM and office BP.

\section{Risk factors for hypertension}

The data on risk factors for development of hypertension are given in Table 1. In summary, no one from the investigated risk factors for hypertension were significantly different in hypertensive in comparison to normotensive children with RCAD syndrome

\section{Echocardiography}

No child from eight investigated children (three hypertensive and five normotensive) had left ventricular hypertrophy.

\section{Discussion}

Arterial hypertension is present in more than $90 \%$ of perinatal diagnosed ARPKD patients [2] and in $35 \%$ of children with ADPKD $[3,4]$. In contrast to this high prevalence of hypertension in children with polycystic kidney diseases, the frequency of hypertension in children with RCAD syndrome is not known. Our study is the first systematic investigation of blood pressure and hypertension in children with RCAD syndrome. We could demonstrate that hypertension is rare in children with RCAD syndrome. Only $14-22 \%$ of children with HNF1ß mutation presented with arterial hypertension, detected by office BP or by ABPM, mainly those with decreased eGFR, i.e. chronic kidney disease stages 2-4. 
In adults with RCAD syndrome the data on prevalence of hypertension are very heterogeneous. Several studies demonstrated prevalence ranging from $0 \%$ to $80 \%[5-7,17]$. A French study on 27 adult patients showed a very low prevalence of hypertension of only $7 \%$ [5]. These authors stated, that this low prevalence of hypertension - together with the slowly progressive kidney function is the hallmark of the RCAD disease [5]. By contrast, an even smaller Brazilian study showed a prevalence of hypertension of $80 \%$ adults with RCAD syndrome [7]. Dubois-Laforgue et al. reported in one of the largest cohort studies on more than 200 adults a prevalence of $58 \%$ of hypertension in patients with RCAD syndrome. The CKD stages 3-5 were the most important risk factors associated with elevated BP. The analysis showed a trend for more hypertension in patients with HNF1ß-mutations in comparison to patients with HNF1B-deletion [6]. In our study, a numerically higher prevalence of hypertension was noted in children with CKD stages 24 (36\%), compared to those patients with CKD stage 1 and normal renal function (14\%). Thus it seems that the prevalence of hypertension in patients with RCAD syndrome depends mainly on the stage of CKD, eGFR and somewhat age of the patients (higher prevalence in adults than in children).

The prevalence of hypertension $14-22 \%$ in our children with RCAD is considerably lower than in children with ARPKD (75\%) [2] or ADPKD (35\%) [3, 4]. The reason for this large discrepancy could be the amount of cystic degeneration of the kidneys being the biggest in patients with ARPKD. Those patients demonstrate the highest prevalence of hypertension and decreased GFR. By contrast, patients with RCAD syndrome have usually normal sized or small kidneys with only small cysts and show a low prevalence of arterial hypertension. This low prevalence of hypertension seems to be the hallmark of this disease in children as it has been stated in adults [5]. Therefore, RCAD syndrome resembles more congenital anomalies of the kidney and urinary tract (CAKUT), where the prevalence of hypertension is also very low [18].

So far, there are no studies dealing primarily with BP or hypertension in children with RCAD syndrome. Thomas et al. investigated patients with $\operatorname{HNF1B}(\mathrm{n}=4)$ and PAX2 gene mutations from the CKiD (Chronic Kidney Disease in Children) study and stated that children with HNF1B and PAX2 gene mutations have normal blood pressure. [19]. Unfortunately, they did not indicate the prevalence of hypertension in this cohort. Only the BP percentiles were mentioned $\left(62^{\text {nd }}\right.$ and $69^{\text {th }}$ for systolic and diastolic BP), which were normal. Other larger studies did not show data on the prevalence of HT or on BP levels [20 - 27]. The relatively low prevalence of hypertension in our cohort and the fairly normal BP in the very small cohort from the CKiD study underline that there is a low prevalence of hypertension among children with RCAD syndrome. This low prevalence seems to be the hallmark of this genetic multisystem disease [5] and is similar to autosomal dominant tubulointerstitial kidney disease [28]. Indeed, one subtype of ADTKD is caused by deletion/mutation of the HNF1B gene (named HNF1B-ADTKD). Moreover, both diseases are primarily tubular diseases which show in general a low prevalence of arterial hypertension.

In our analysis, it was very difficult to discover risk factors for hypertension in the few hypertensive children with RCAD syndrome due to the very low number of hypertensive patients $(n=7)$. We did not find any statistically significant marker associated with arterial hypertension. The only trend for higher prevalence of hypertension was CKD stages 2-4. This finding is in line with published data from the 
largest adult cohort study demonstrating CKD stages 3-5 being the only risk factor for the development of hypertension [6]. In adult and pediatric patients with ADPKD the kidney size is positively associated with BP and patients with larger kidney size have higher risk of hypertension $[4,29,30]$. In our cohort of children with RCAD syndrome, only $10 \%$ of children had enlarged kidneys, a percentage similarly low to the prevalence of hypertension. Furthermore, more children (40\%) had small kidneys or unilateral renal agenesis that do not cause hypertension.

In conclusion, we have demonstrated that children with renal cyst and diabetes syndrome have a low prevalence of arterial hypertension. This seems to be the hallmark of the disease in children.

\section{List Of Abbreviations}

ABPM Ambulatory blood pressure monitoring

ACEI angiotensin-converting enzyme inhibitor

ADPKD autosomal dominant polycystic kidney disease

ADTKD autosomal dominant tubulointerstitial kidney disease

ARPKD autosomal recessive polycystic kidney disease

BP blood pressure

CAKUT congenital anomalies of the kidney and urinary tract

CKD chronic kidney disease

$H N F 1 B$ hepatocyte nuclear factor $1 \beta$

HT hypertension

LVH left ventricular hypertrophy

LVMI left ventricular mass index

MODY maturity onset diabetes of the young

RCAD renal cysts and diabetes syndrome

\section{Declarations}

Funding: The authors did not receive support from any organization for the submitted work.

Conflict of interest: The authors declare they have no financial interests. 
Availability of data and material: Not applicable

Authors' contributions: TS and UJK made substantial contributions to the conception and design of the work. TS collected, analyzed and interpreted the clinical data and wrote the manuscript, FW, BW and FF collected the clinical data. $\mathrm{KH}, \mathrm{RK}$ and BLS collected clinical data and wrote part of the manuscript and VG made the statistical analyses.

Ethics approval: The present study was conducted in accordance with the principles outlined in the Declaration of Helsinki with approval from the Ethics Committee of LMU Munich and CHU Prague. Formal written informed consent could not be obtained from the patients' parents or patients due to the retrospective design of the study.

\section{Consent to participate: N/A}

\section{Consent for publication: N/A}

\section{Acknowledgements}

We would like to thank Jan Janda for critical reading of our manuscript.

\section{References}

1. Gimpel C, Bergmann C, Bockenhauer D, Breysem L, Cadnapaphornchai MA, Cetiner M, Dudley J, Emma F, Konrad M, Harris T, Harris PC, König J, Liebau MC, Marlais M, Mekahli D, Metcalfe AM, Oh J, Perrone RD, Sinha MD, Titieni A, Torra R, Weber S, Winyard PJD, Schaefer F (2019) International consensus statement on the diagnosis and management of autosomal dominant polycystic kidney disease in children and young people. Nat Rev Nephrol 15:713-726

2. Guay-Woodford LM, Bissler JJ, Braun MC, Bockenhauer D, Cadnapaphornchai MA, Dell KM, Kerecuk L, Liebau MC, Alonso-Peclet MH, Shneider B, Emre S, Heller T, Kamath BM, Murray KF, Moise K, Eichenwald EE, Evans J, Keller RL, Wilkins-Haug L, Bergmann C, Gunay-Aygun M, Hooper SR, Hardy KK, Hartung EA, Streisand R, Perrone R, Moxey-Mims M (2014) Consensus expert recommendations for the diagnosis and management of autosomal recessive polycystic kidney disease: report of an international conference. J Pediatr. 165:611-617

3. Seeman T, Sikut M, Konrad M, Vondrichová H, Janda J, Schärer K (1997) Blood pressure and renal function in autosomal dominant polycystic kidney disease. Pediatr Nephrol 11:592-596

4. Massella L, Mekahli D, Paripović D, Prikhodina L, Godefroid N, Niemirska A, Ağbaş A, Kalicka K, Jankauskiene A, Mizerska-Wasiak M, Afonso AC, Salomon R, Deschênes G, Ariceta G, Özçakar ZB, Teixeira A, Duzova A, Harambat J, Seeman T, Hrčková G, Lungu AC, Papizh S, Peco-Antic A, De Rechter S, Giordano U, Kirchner M, Lutz T, Schaefer F, Devuyst O, Wühl E, Emma F (2018) Prevalence of Hypertension in Children with Early-Stage ADPKD. Clin J Am Soc Nephrol 13:874-883 
5. Faguer S, Decramer S, Chassaing N, Bellanné-Chantelot C, Calvas P, Beaufils S, Bessenay L, Lengelé JP, Dahan K, Ronco P, Devuyst O, Chauveau D (2011) Diagnosis, management, and prognosis of HNF1B nephropathy in adulthood. Kidney Int 80:768-776

6. Dubois-Laforgue D, Cornu E, Saint-Martin C, Coste J, Bellanné-Chantelot C, Timsit J (2017) Monogenic Diabetes Study Group of the Société Francophone du Diabète. Diabetes, Associated Clinical Spectrum, Long-term Prognosis, and Genotype/Phenotype Correlations in 201 Adult Patients With Hepatocyte Nuclear Factor 1B (HNF1B) Molecular Defects. Diabetes Care 40:1436-1443

7. Dotto RP, Santana LS, Lindsey SC, Caetano LA, Franco LF, Moisés RCMS, Sa JR, Nishiura JL, Teles MG, Heilberg IP, Dias-da-Silva MR, Giuffrida FMA, Reis AF (2019) Searching for mutations in the HNF1B gene in a Brazilian cohort with renal cysts and hyperglycemia. Arch Endocrinol Metab 63:250-257

8. Lurbe E, Agabiti-Rosei E, Cruickshank JK, Dominiczak A, Erdine S, Hirth A, Invitti C, Litwin M, Mancia G, Pall D, Rascher W, Redon J, Schaefer F, Seeman T, Sinha M, Stabouli S, Webb NJ, Wühl E, Zanchetti A (2016) 2016 European Society of Hypertension guidelines for the management of high blood pressure in children and adolescents. J Hypertens 34:1887-1920

9. Wühl E, Witte K, Soergel M, Mehls O, Schaefer F, Kirchstein M, Busch C, Danne T, Gellermann J, Holl R, Krull F, Reichert H, Reusz GS, Rascher W (2002) German Working Group on Pediatric Hypertension: Distribution of 24-h ambulatory blood pressure in children: normalized reference values and role of body dimensions. J Hypertens 20:1995-2007

10. Kidney Disease: Improving Global Outcomes (KDIGO) CKD Work Group (2013) KDIGO 2012 clinical practice guideline for the evaluation and management of chronic kidney disease. Kidney Int Suppl 3:1-150

11. Schwartz GJ, Muñoz A, Schneider MF, Mak RH, Kaskel F, Warady BA, Furth SL (2009) New equations to estimate GFR in children with CKD. J Am Soc Nephrol 20:629-637

12. Dinkel E, Ertel M, Dittrich M, Peters H, Berres M, Schulte-Wissermann H (1985) Kidney size in childhood: sonographical growth charts for kidney length and volume. Pediatr Radiol 15:38-43

13. Sahn DJ, DeMaria A, Kisslo J, Weyman A (1978) Recommendations regarding quantitation in Mmode echocardiography: results of a survey of Echocardiographic measurements. Circulation 58:1072-1083

14. Devereux RB, Alonso DR, Lutas EM, Gottlieb GJ, Campo E, Sachs I, Reichek N (1986) Echocardiographic assessment of left ventricular hypertrophy: comparison to necropsy findings. Am J Cardiol 57:450-458

15. Daniels SR, Kimball TR, Morrison JA, Khoury P, Meyer RA (1995) Indexing left ventricular mass to account for differences in body size in children and adolescents without cardiovascular disease. Am J Cardiol 76:699-701

16. Khoury PR, Mitsnefes M, Daniels SR, Kimball TR (2009) Age-specific reference intervals for indexed left ventricular mass in children. J Am Soc Echocardiogr 22:709-714 
17. Bellanné-Chantelot C, Chauveau D, Gautier JF, Dubois-Laforgue D, Clauin S, Beaufils S, Wilhelm JM, Boitard C, Noël LH, Velho G, Timsit J (2004) Clinical spectrum associated with hepatocyte nuclear factor-1beta mutations. Ann Intern Med 140:510-517

18. Sanna-Cherchi S, Ravani P, Corbani V, Parodi S, Haupt R, Piaggio G, Innocenti ML, Somenzi D, Trivelli A, Caridi G, Izzi C, Scolari F, Mattioli G, Allegri L, Ghiggeri GM (2009) Renal outcome in patients with congenital anomalies of the kidney and urinary tract. Kidney Int 76:528-533

19. Thomas R, Sanna-Cherchi S, Warady BA, Furth SL, Kaskel FJ, Gharavi AG (2011) HNF1B and PAX2 mutations are a common cause of renal hypodysplasia in the CKiD cohort. Pediatr Nephrol 26:897903

20. Ulinski T, Lescure S, Beaufils S, Guigonis V, Decramer S, Morin D, Clauin S, Deschênes G, Bouissou F, Bensman A, Bellanné-Chantelot C (2006) Renal phenotypes related to hepatocyte nuclear factor1 beta (TCF2) mutations in a pediatric cohort. J Am Soc Nephrol 17:497-503

21. Weber S, Moriniere V, Knüppel T, Charbit M, Dusek J, Ghiggeri GM, Jankauskiené A, Mir S, Montini G, Peco-Antic A, Wühl E, Zurowska AM, Mehls O, Antignac C, Schaefer F, Salomon R (2006) Prevalence of mutations in renal developmental genes in children with renal hypodysplasia: results of the ESCAPE study. J Am Soc Nephrol 17:2864-2870

22. Nakayama M, Nozu K, Goto Y, Kamei K, Ito S, Sato H, Emi M, Nakanishi K, Tsuchiya S, lijima K (2010) HNF1B alterations associated with congenital anomalies of the kidney and urinary tract. Pediatr Nephrol 25:1073-1079

23. Bockenhauer D, Jaureguiberry G (2016) HNF1B-associated clinical phenotypes: the kidney and beyond. Pediatr Nephrol 31:707-714

24. Okorn C, Goertz A, Vester U, Beck BB, Bergmann C, Habbig S, König J, Konrad M, Müller D, Oh J, OrtizBrüchle N, Patzer L, Schild R, Seeman T, Staude H, Thumfart J, Tönshoff B, Walden U, Weber L, Zaniew M, Zappel H, Hoyer PF, Weber S (2019) HNF1B nephropathy has a slow-progressive phenotype in childhood-with the exception of very early onset cases: results of the German Multicenter HNF1B Childhood Registry. Pediatr Nephrol 34:1065-1075

25. Nagano C, Morisada N, Nozu K, Kamei K, Tanaka R, Kanda S, Shiona S, Araki Y, Ohara S, Matsumura C, Kasahara K, Mori Y, Seo A, Miura K, Washiyama M, Sugimoto K, Harada R, Tazoe S, Kourakata H, Enseki M, Aotani D, Yamada T, Sakakibara N, Yamamura T, Minamikawa S, Ishikura K, Ito S, Hattori M, lijima K (2019) Clinical characteristics of HNF1B-related disorders in a Japanese population. Clin Exp Nephrol 23:1119-1129

26. Lim SH, Kim JH, Han KH, Ahn YH, Kang HG, Ha IS, Cheong HI (2020) Genotype and Phenotype Analyses in Pediatric Patients with HNF1B Mutations. J Clin Med 9:2320

27. Chen YZ, Gao Q, Zhao XZ, Chen YZ, Bennett CL, Xiong XS, Mei CL, Shi YQ, Chen XM (2010) Systematic review of TCF2 anomalies in renal cysts and diabetes syndrome/maturity onset diabetes of the young type 5. Chin Med J (Engl) 123:3326-3333

28. Eckardt KU, Alper SL, Antignac C, Bleyer AJ, Chauveau D, Dahan K, Deltas C, Hosking A, Kmoch S, Rampoldi L, Wiesener M, Wolf MT, Devuyst O (2015) Kidney Disease: Improving Global Outcomes. 
Autosomal dominant tubulointerstitial kidney disease: diagnosis, classification, and management-A KDIGO consensus report. Kidney Int 88:676-683

29. Seeman T, Dusek J, Vondrichová H, Kyncl M, John U, Misselwitz J, Janda (2003) Ambulatory blood pressure correlates with renal volume and number of renal cysts in children with autosomal dominant polycystic kidney disease. Blood Press Monit 8:107-110

30. Schrier RW (2009) Renal volume, renin-angiotensin-aldosterone system, hypertension, and left ventricular hypertrophy in patients with autosomal dominant polycystic kidney disease. J Am Soc Nephrol 20:1888-1893

\section{Tables}

Table 1 Biochemical, clinical and renal ultrasound data in normotensive and hypertensive children with renal cyst and diabetes syndrome 


\begin{tabular}{|c|c|c|c|c|}
\hline & $\begin{array}{c}\text { All } \\
\text { patients } \\
(\mathrm{n}=32)\end{array}$ & $\begin{array}{c}\text { Normotensive } \\
\text { patients } \\
(n=25)\end{array}$ & $\begin{array}{c}\text { Hypertensive } \\
\text { patients } \\
(\mathrm{n}=7)\end{array}$ & $\begin{array}{c}\mathrm{P} \\
\text { value }\end{array}$ \\
\hline Age (years) & $\begin{array}{l}3.0(0.3- \\
18.5)\end{array}$ & $2.9(0.3-18.5)$ & $3.9(2.9-18.4)$ & 0.16 \\
\hline Sex (boys) & $29 \%$ & $30 \%$ & $28 \%$ & 0.89 \\
\hline CKD stages $2-4$ & $34 \%$ & $28 \%$ & $57 \%$ & 0.15 \\
\hline $\begin{array}{c}\text { Creatinine clearance } \\
(\mathrm{ml} / \mathrm{min} / 1.73 \mathrm{~m} 2)\end{array}$ & $90(8-19)$ & $90(8-193)$ & $68(13-142)$ & 0.12 \\
\hline $\begin{array}{c}\text { Proteinuria } \\
\text { (mg/mmol creatinine) }\end{array}$ & $\begin{array}{l}26(3- \\
104)\end{array}$ & $27(3-82)$ & $25(7-104)$ & 0.58 \\
\hline $\begin{array}{l}\text { Pathological proteinuria } \\
\text { (>40 mg/mmol creatinine) }\end{array}$ & $58 \%$ & $58 \%$ & $57 \%$ & 0.97 \\
\hline $\begin{array}{c}\text { Albuminuria } \\
\text { (mg/mmol creatinine) }\end{array}$ & $1.2(0-44)$ & $1.0(0-44)$ & $2.9(0.5-12.6)$ & 0.58 \\
\hline $\begin{array}{l}\text { Pathological albuminuria } \\
\text { (>3.0 } \mathrm{mg} / \mathrm{mmol} \text { creatinine) }\end{array}$ & $40 \%$ & $36 \%$ & $50 \%$ & 0.55 \\
\hline BMI $\left(\mathrm{kg} / \mathrm{m}^{2}\right)$ & $\begin{array}{l}16.7 \\
(12.9- \\
26.5) \\
\end{array}$ & $\begin{array}{r}17.2 \\
(12.9-26.5)\end{array}$ & $\begin{array}{l}16.0 \\
(14.4-24.2)\end{array}$ & 0.98 \\
\hline HNF1 gene deletion & $72 \%$ & $76 \%$ & $57 \%$ & 0.32 \\
\hline $\begin{array}{l}\text { Left kidney length } \\
\text { (SDS) }\end{array}$ & $\begin{array}{l}-0.9 \\
(-5.1 \text { to } \\
2.5)\end{array}$ & $\left(-5.1^{-0.6}\right.$ to 2.5$)$ & $(-2.0$ to 0.0$)$ & 0.34 \\
\hline $\begin{array}{l}\text { Right kidney length } \\
\text { (SDS) }\end{array}$ & $\begin{array}{c}-0.8 \\
(-3.6 \text { to } \\
2.1)\end{array}$ & $\left(-3.3^{-0.7}\right.$ to 2.1$)$ & $\begin{array}{c}-0.8 \\
(-3.6 \text { to } 0.0)\end{array}$ & 0.36 \\
\hline Enlarged kidneys & $10 \%$ & $13 \%$ & $0 \%$ & 0.36 \\
\hline $\begin{array}{c}\text { Small kidney(s) or } \\
\text { agenesis }\end{array}$ & $40 \%$ & $42 \%$ & $33 \%$ & 0.71 \\
\hline Oligohydramnios & $18 \%$ & $14 \%$ & $29 \%$ & 0.39 \\
\hline SGA & $10 \%$ & $13 \%$ & $0 \%$ & 0.35 \\
\hline MODY & $13 \%$ & $9 \%$ & $25 \%$ & 0.48 \\
\hline $\begin{array}{l}\text { Hypomagnesemia } \\
(<0.70 \mathrm{mmol} / \mathrm{l})\end{array}$ & $53 \%$ & $56 \%$ & $43 \%$ & 0.78 \\
\hline Liver abnormalities & $22 \%$ & $24 \%$ & $14 \%$ & 0.51 \\
\hline
\end{tabular}

Data are given as median (range) or as relative frequency

CKD chronic kidney disease

BMI body mass index

SGA small for gestational age

MODY maturity onset diabetes of the young 
Page 14/14 